\title{
EMBRIOGENESIS DAN PERKEMBANGAN LARVA PATIN HASIL HIBRIDISASI ANTARA BETINA IKAN PATIN SIAM (Pangasianodon hypophthalmus Sauvage, 1878) DENGAN JANTAN IKAN PATIN JAMBAL (Pangasius djambal Bleeker, 1846) DAN JANTAN PATIN NASUTUS (Pangasius nasutus Bleeker, 1863)
}

\author{
Bambang Iswanto dan Evi Tahapari \\ Loka Riset Pemuliaan dan Teknologi Budidaya Perikanan Air Tawar \\ Jl. Raya 2 Sukamandi, Subang, Jawa Barat 41256 \\ E-mail: bambang.is031@gmail.com
}

(Naskah diterima: 17 Januari 2011; Disetujui publikasi: 28 Mei 2011)

\begin{abstract}
ABSTRAK
Pengembangan budidaya ikan patin jambal maupun ikan patin nasutus untuk memenuhi permintaan pasar ekspor patin daging putih sulit direalisasikan karena keterbatasan fekunditas dan pematangan gonad induk betinanya. Salah satu upaya yang dapat dilakukan untuk meningkatkan produktivitas patin daging putih adalah melalui hibridisasi, yakni hibridisasi antara betina patin siam dengan jantan patin jambal maupun jantan patin nasutus. Hal ini dikarenakan patin siam memiliki keunggulan fekunditas yang tinggi, sedangkan patin jambal maupun patin nasutus memiliki keunggulan daging yang putih. Oleh karena itu, perlu dilakukan penelitian untuk mengetahui karakteristik patin hibrida tersebut, termasuk pada tahap-tahap awal kehidupannya. Penelitian ini bertujuan untuk mengetahui karakteristik embriogenesis dan perkembangan ontogeni morfologis larva patin hibrida tersebut. Hasil penelitian ini menunjukkan bahwa embriogenesis patin hibrida siam-jambal dan hibrida siam- nasutus serupa, tetapi perkembangan patin hibrida siam- nasutus sedikit lebih cepat. Pada suhu $28^{\circ} \mathrm{C}-29^{\circ} \mathrm{C}$, larva patin hibrida siam- nasutus mulai menetas 20 jam setelah fertilisasi, berukuran

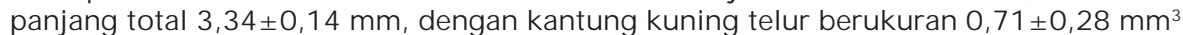
yang terserap 50\% pada umur 24 jam dan relatif habis terserap pada umur 54 jam. Larva patin hibrida siam-jambal mulai menetas 21 jam setelah fertilisasi, berukuran panjang total $3,47 \pm 0,13 \mathrm{~mm}$, dengan kantung kuning telur berukuran 0,42 $00,08 \mathrm{~mm}^{3}$ yang terserap 50\% pada umur 30 jam dan habis terserap pada umur 60 jam. Perkembangan larva kedua patin hibrida tersebut hingga menyerupai morfologi ikan patin dewasa juga relatif serupa, tetapi patin hibrida siam- nasutus menunjukkan keragaan pertumbuhan yang lebih bagus, menghasilkan heterosis berdasarkan pertambahan panjang total selama 10 hari masa pemeliharaan sebesar 20,20\% sedangkan pada patin hibrida siam- jambal sebesar - 4,15\%
\end{abstract}

KATA KUNCI: embrio, larva, hibrida, siam, jambal, nasutus

ABSTRACT: Embryogenesis and larval development of pangasius hybrids produced from female Pangasianodon hypophthalmus Sauvage, 1878 and male Pangasius djambal Bleeker, 1846 and Pangasius nasutus Bleeker, 1863. By: Bambang Iswanto and Evi Tahapari

The development of Pangasius djambal and P. nasutus culture which is intended supply international market needs with white flesh pangasiid catfish is still difficult to be actualized due to their limited fecundity and mature capability of female 
brooders. Hybridization could be one of the alternatives to increase the productivity of white flesh pangasiid catfish, i.e. through hybridization between female $\boldsymbol{P}$. hypophthalmus and male P. djambal or P. nasutus. P. hypophthalmus has higher fecundity rate and both of $\boldsymbol{P}$. djambal and $\boldsymbol{P}$. nasutus have white flesh. It is then important to find out if the hybrids of those fish have the superior characteristics, especially at the early life stages. The research was aimed to characterize the embryonic and larval development of the hybrids. The result showed that embryogenesis of both hybrids were similar. However, embryogenesis of $\boldsymbol{P}$. hypophthalmus $X \boldsymbol{P}$. nasutus hybrid occured rapidly. At $28^{\circ} \mathrm{C}-29^{\circ} \mathrm{C}$ of water temperature, $\boldsymbol{P}$. hypophthalmus $X \boldsymbol{P}$. nasutus hybrid larvae started to hatch 20 hours after fertilization with larval average length of $3.34 \pm 0.14 \mathrm{~mm}$ and yolk sac volume of $0.71 \pm 0.28 \mathrm{~mm}^{3}$. As much as $50 \%$ of yolk sac was absorbed during the 24 hours after hatching and was completely absorbed at 54 hours after hatching. Hatching of $\boldsymbol{P}$. hypophthalmus X P. djambal hybrid larvae started at 21 hours after fertilization with larval average length of $3.47 \pm 0.13 \mathrm{~mm}$ and yolk sac volume of $0.42 \pm 0.08 \mathrm{~mm}^{3} .50 \%$ of the yolk sac was absorbed at 30 hours after hatching and was completely absorbed at 60 hours after hatching. Larval development of both hybrids was also quite similar, but $\boldsymbol{P}$. hypophthalmus $X$ P. nasutus hybrid showed better growth performance, resulted in mid-parent heterosis based on the total length gain after 10 days rearing period of $20.20 \%$, while in P. hypophthalmus X P. djambal hybrid was $-4.15 \%$.

KEYWORDS: embryo, larvae, hybrid, P. hypophthalmus, P. djambal, P. nasutus

\section{PENDAHULUAN}

Patin merupakan salah satu komoditas perikanan air tawar yang diunggulkan oleh Kementerian Kelautan dan Perikanan, terutama sebagai komoditas ekspor patin daging putih. Indonesia memiliki 14 spesies dari 28 spesies patin yang telah diidentifikasi (Gustiano, 2009), dengan patin jambal (P. djambalBleeker, 1846), patin nasutus ( $P$. nasutus Bleeker, 1863 ) dan patin kunyit ( $P$. kunyit Pouyaud, Teugels \& Legendre, 1999) merupakan spesies- spesies yang potensial untuk dikembangkan sebagai komoditas perikanan budidaya (Pouyaud et al., 1999; Legendre et al., 2000b; Legendre, 2008). Namun demikian, spesies patin yang telah dibudidayakan secara luas di Indonesia terutama adalah patin siam ( $P$. hypophthalmus Sauvage, 1878) yang diintroduksi dari Thailand sejak tahun 1972 (Hardjamulia et al., 1981; Legendre et al., 1998b; 1998c; 2000a) dan patin jambal yang telah berhasil didomestikasikan (Sudarto, 1999; Legendre et al., 1998a; 2000b), sedangkan patin nasutus masih dalam tahap domestikasi (Legendre et al., 2000b; Tahapari et al., 2008) dan patin kunyit belum diupayakan proses domestikasinya.

Patin jambal dan nasutus memiliki daging yang berwarna putih, memenuhi standar kualitas ekspor patin daging putih, tetapi fekunditasnya rendah dan proses pematangan gonad induk betina serta keberhasilan pemijahan buatannya sulit dicapai pada musim kemarau (LRPTBPAT, 2006; Tahapari et al., 2008; 2010b), sehingga upaya pengembangan budidayanya sebagai komoditas ekspor patin daging putih sulit direalisasikan. Sebaliknya, patin siam telah terdomestikasi dengan baik di Indonesia, pemijahan buatannya mudah dilakukan dan dapat dipijahkan sepanjang tahun serta merupakan spesies patin yang memiliki fekunditas tinggi dan toleran terhadap berbagai kondisi media pemeliharaan (Cacot, 1998; Legendre et al., 1998b; 1998c; 2000a; Jalabert, 2008), tetapi dagingnya berwarna kuning, sehingga nilainya sebagai komoditas ekspor relatif rendah (Jalabert, 2008; Tahapari et al., 2010b).

Salah satu upaya yang dapat dilakukan untuk meningkatkan produktivitas patin daging putih adalah melalui hibridisasi. Hibridisasi dalam upaya meningkatkan produktivitas dapat dicapai melalui persilangan antara betina spesies ikan yang telah terdomestikasi dan berfekunditas tinggi, tetapi memiliki kekurangan pada karakter tertentu, dengan spesies ikan lain yang memiliki keunggulan pada karakter tertentu tersebut, tetapi produktivitasnya rendah atau belum terdomestikasi (Chevassus, 1983). Upaya peningkatan produktivitas patin daging putih dapat dicapai melalui hibridisasi antara betina patin siam (berfekunditas tinggi, telah terdomestikasi dengan baik dan dapat dipijahkan 
sepanjang tahun, tetapi berdaging kuning) dengan jantan patin jambal maupun patin nasutus (berdaging putih). Hibridisasi antara betina patin siam dengan jantan patin jambal telah dilakukan dan karakteristik morfometrik, meristik, pertumbuhan, daging dan biologireproduksi hibridanya telah diidentifikasi (Gustiano, 2004; LRPTBPAT, 2006; Gustiano \& Kristanto, 2007; Tahapari et al., 2007), sedangkan hibridisasi antara betina patin siam dengan jantan patin nasutus masih dalam tahap karakterisasi (identifikasi). Namun demikian, informasi karakteristik perkem- bangan embrio dan larva kedua patin hibrida tersebut belum ada. Penelitian ini bertujuan untuk mengetahui karakteristik embriogenesis dan perkembangan larva patin hibrida hasil hibridisasi antara betina patin siam dengan jantan patin jambal (patin hibrida siam- jambal) dan dengan jantan patin nasutus (patin hibrida siamnasutus).

\section{BAHAN DAN METODE}

\section{Pemijahan Buatan dan Pemeliharaan Larva}

Induk- induk patin siam, nasutus dan jambal yang dipergunakan pada penelitian ini dipelihara dalam kolam tanah berukuran 200 $\mathrm{m}^{2}$ di Loka Riset Pemuliaan dan Teknologi Budidaya Perikanan Air Tawar (LRPTBPAT), Sukamandi. Pakan yang diberikan berupa pelet komersial dengan kadar protein $28 \%$ sebanyak $2 \%$ biomassa per hari, diberikan pada pagi dan sore hari.

Pemilihan induk betina yang akan dipergunakan dilakukan melalui pengambilan sampel oosit intraovarian dengan cara kanulasi (intraovarian biopsy) menggunakan kateter. Sampel oosit intraovarian masing- masing induk betina selanjutnya diamati dan diukur dengan mikroskop binokuler yang telah dilengkapi mikrometer terkalibrasi pada perbesaran 4x10. Induk betina dipilih yang telah matang gonad dengan modus diameter oosit lebih dari 0,90 mm untuk patin siam, lebih dari $1,40 \mathrm{~mm}$ untuk patin nasutus dan lebih dari $1,70 \mathrm{~mm}$ untuk patin jambal. Induk- induk jantan patin siam, jambal dan nasutus dipilih yang telah matang gonad, yakni dapat mengeluarkan cairan sperma ketika dilakukan sedikit pengurutan (stripping) pada papila genitalia.

Induksi stimulasi hormonal dilakukan terhadap induk betina dan jantan yang terpilih. Penyuntikan terhadap induk betina dilakukan dua kali dengan selang waktu penyuntikan selama 24 jam. Penyuntikan pertama terhadap induk betina dilakukan dengan hormon gonadotropin, yakni hCG (human chorionic gonadotropin) menggunakan CHORULON ${ }^{\circledR}$ dengan dosis $500 \mathrm{lU} / \mathrm{kg}$ induk. Penyuntikan kedua terhadap induk betina dilakukan dengan kombinasi gonadotropin releasing hormone analogue (GnRHa) dan antidopamin (domperidone) menggunakan OVAPRIM ${ }^{\circledR}$ dengan dosis $0,6 \mathrm{~mL} / \mathrm{kg}$ induk. Penyuntikan terhadap induk jantan dilakukan satu kali bersamaan dengan penyuntikan kedua terhadap induk betina menggunakan OVAPRIM ${ }^{\circledR}$ dengan dosis $0,2 \mathrm{~mL} / \mathrm{kg}$ induk.

Sperma hasil pengurutan ditampung dalam botol, dan diencerkan dengan larutan 0,9\% $\mathrm{NaCl}$ fisiologis, dengan perbandingan volume sperma dan volume $\mathrm{NaCl}$ fisiologis sebanyak 1:5. Setelah sperma diperoleh, selanjutnya dilakukan pengambilan telur melalui pengurutan. Fertilisasi dilakukan dengan metode kering (dry method). Aktivasi proses fertilisasi dilakukan menggunakan air mineral Telur patin siam difertilisasi dengan sperma patin jambal untuk membentuk patin hibrida siam- jambal, sperma patin nasutus untuk membentuk patin hibrida siam- nasutus dan sperma patin siam sendiri. Telur patin jambal dan nasutus hanya difertilisasi dengan sperma masing-masing spesies patin tersebut. Inkubasi telur dilakukan dalam corong penetasan dengan air media inkubasi yang tersirkulasi.

Larva- larva hasil penetasan dipelihara dalam bak fiberglass berukuran 500 liter di dalam ruangan pemeliharaan larva, dengan kepadatan 50 ekor larva per liter. Selama pemeliharaan diberikan pakan berupa nauplii Artemia sp. sejak hari kedua hingga hari kelima, selanjutnya hingga hari kesepuluh secara bertahap diganti dengan kutu air (Moina sp.) beku atau larva cacing darah (Chironomus sp.) beku yang dicincang, setelah itu secara bertahap diberikan cacing sutera (Tubifex sp.) hingga umur 12 hari, kemudian mulai diperkenalkan dengan pakan buatan komersial berbentuk halus dengan kadar protein $40 \%$

\section{Identifikasi Perkembangan Embrio dan Larva}

Pengamatan perkembangan embrio dan larva pada penelitian ini dilakukan dengan mengacu pada perkembangan embrio dan larva patin jambal (Slembrouck et al., 2003a), patin siam (Islam, 2005) dan patin nasutus 
(Tahapari et al., 2010a). Masing-masing sebanyak 200 butir telur sampel yang telah difertilisasi dan akan diamati perkembangannya ditempatkan dalam wadah-wadah plastik tembus cahaya berisi $300 \mathrm{~mL}$ air mineral. Wadah- wadah tersebut ditempatkan dalam ruang inkubasi dengan suhu air media inkubasi $28^{\circ} \mathrm{C}-29^{\circ} \mathrm{C}$. Pengamatan dilakukan dengan mikroskop stereo yang dilengkapi dengan kamera digital. Pengamatan dan dokumentasi dilakukan secara terus- menerus sejak proses fertilisasi sampai terjadinya penetasan.

Pengamatan perkembangan ontogeni morfologis dan pertumbuhan larva dilakukan secara terus- menerus selama tahap pemeliharaan di dalam ruangan sejak larva menetas hingga telah memiliki kelengkapan organorgan seperti pada ikan patin dewasa (maksimum selama 10 hari), sebagaimana definisi istilah larva yang diberikan oleh Blaxter (1988) dan Fuiman (2002), yakni periode perkembangan sejak penetasan sampai berakhirnya perubahan- perubahan morfologis (metamorfosis) sehingga telah memiliki kelengkapan organ- organ menyerupai ikan dewasa. Pengamatan, pengukuran, dan dokumentasi perkembangan ontogeni morfologis larva dilakukan dengan menggunakan mikroskop stereo yang dilengkapi dengan mikrometer okuler dan kamera digital. Jumlah sampel larva yang diamati masingmasing sebanyak 30 ekor.

\section{HASIL DAN BAHASAN}

\section{Embriogenesis}

Diameter oosit patin siam yang distimulasi secara hormonal dan dipergunakan dalam hibridisasi dengan sperma patin jambal dan nasutus pada penelitian ini berkisar 0,80- 1,15 $\mathrm{mm}$, dengan modus berkisar 0,90-1,10 mm (Gambar 1A). Diameter telur terovulasi (hasil pengurutan) berkisar 0,95-1,20 mm, dengan modus berkisar 1,05-1,15 mm (Gambar 1B). Sesaat setelah terfertilisasi, telur mengalami hidrasi sehingga terbentuk ruang perivitelin yang memisahkan telur dari membran telur, dan diameter telur menjadi berkisar 1,10-1,20 mm, dengan modus 1,15 mm (Gambar 1C). Diameter oosit intraovarian patin nasutus yang dipergunakan dalam proses induksi stimulasi hormonal pada penelitian ini berkisar 1,30-1,60 $\mathrm{mm}$, sedangkan pada patin jambal berkisar 1,20-1,75 mm. Diameter telur patin nasutus hasil pengurutan berkisar 1,40-1,65 mm, sedangkan pada patin jambal berkisar 1,70 $1,95 \mathrm{~mm}$. Diameter telur patin nasutus terfertilisasi berkisar 1,90-2,15 mm, sedangkan pada patin jambal berkisar 1,95- 2,20 mm.

Proses embriogenesis patin hibrida siamjambal dan hibrida siam- nasutus pada suhu media inkubasi $28^{\circ} \mathrm{C}-29^{\circ} \mathrm{C}$ hingga menetas pada penelitian ini disajikan pada Tabel 1 dan Gambar 2.

Proses embriogenesis patin hibrida siamjambal dan patin hibrida siam- nasutus serupa, tetapi waktu yang diperlukan bagi masingmasing tahap perkembangan relatif berbeda, yakni sedikit lebih cepat pada patin hibrida siam- nasutus (Tabel 1). Tahap perkembangan 1 sel ditandai dengan terbentuknya sel tunggal (blastodisc) berukuran besar yang tampak lebih padat dibandingkan bagian kuning telur (Gambar 2A). Perkembangan selanjutnya adalah tahap- tahap pembelahan sel (morulasi). Pembelahan yang pertama
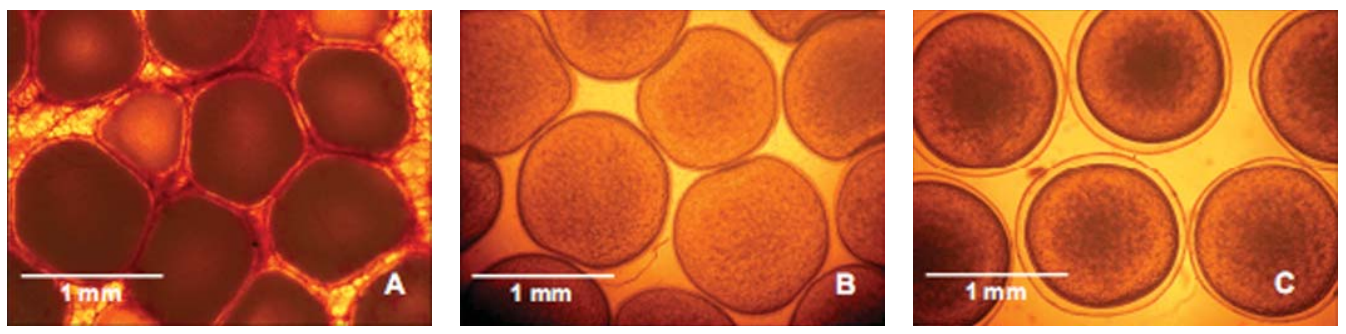

Gambar 1. Oosit dan telur patin siam. Oosit intraovarian yang diinduksi secara hormonal (A), oosit terovulasi hasil pengurutan yang dipergunakan dalam proses hibridisasi buatan (B) dan telur terfertilisasi (C)

Figure 1. Oocytes and eggs of P. hypophthalmus. Intraovarian oocytes used in induced breeding (A), ovulated (stripped) oocytes used in artificial hybridization (B) and fertilized eggs $(C)$ 
Tabel 1. Embriogenesis patin hibrida siam- jambal dan hibrida siam- nasutus

Table 1. Embryogenesis of P. hypophthalmus X P. djambal hybrid, and P. hypophthalmus $X$ P. nasutus hybrid

\begin{tabular}{|c|c|c|}
\hline $\begin{array}{l}\text { Tahap } \\
\text { Stage }\end{array}$ & $\begin{array}{l}\text { Hibrida siamjambal } \\
\text { P. hypopthalmus XP. } \\
\text { djambal hybrid }\end{array}$ & $\begin{array}{c}\text { Hibrida siam-nasutus } \\
\text { P. hypophthalmus XP. } \\
\text { nasutus hybrid }\end{array}$ \\
\hline $1 \mathrm{sel}$ & $\begin{array}{l}\text { Terjadi dalam periode } 10-40 \\
\text { menit setelah fertilisasi }\end{array}$ & $\begin{array}{l}\text { Terjadi dalam periode } 10-30 \\
\text { menit setelah fertilisasi }\end{array}$ \\
\hline Single cell & $\begin{array}{l}\text { Occured within } 10-40 \text { minutes } \\
\text { after fertilization }\end{array}$ & $\begin{array}{l}\text { Occured within } 10-30 \text { minutes } \\
\text { after fertilization }\end{array}$ \\
\hline $2 \mathrm{sel}$ & $\begin{array}{l}\text { Terjadi dalam periode } 20-50 \\
\text { menit setelah fertilisasi }\end{array}$ & $\begin{array}{l}\text { Terjadi dalam periode } 20-50 \\
\text { menit setelah fertilisasi }\end{array}$ \\
\hline 2 cells & $\begin{array}{l}\text { Occured within } 20-50 \text { minutes } \\
\text { after fertilization }\end{array}$ & $\begin{array}{l}\text { Occured within } 20-50 \text { minutes } \\
\text { after fertilization }\end{array}$ \\
\hline $4 \mathrm{sel}$ & $\begin{array}{l}\text { Terjadi dalam periode } 30-80 \\
\text { menit setelah fertilisasi }\end{array}$ & $\begin{array}{l}\text { Terjadi dalam periode } 30-80 \\
\text { menit setelah fertilisasi }\end{array}$ \\
\hline 4 cells & $\begin{array}{l}\text { Occured within } 30-80 \text { minutes } \\
\text { after fertilization }\end{array}$ & $\begin{array}{l}\text { Occured within } 30-80 \text { minutes } \\
\text { after fertilization }\end{array}$ \\
\hline $8 \mathrm{sel}$ & $\begin{array}{l}\text { Terjadi dalam periode } 40-90 \\
\text { menit setelah fertilisasi }\end{array}$ & $\begin{array}{l}\text { Terjadi dalam periode } 40-90 \\
\text { menit setelah fertilisasi }\end{array}$ \\
\hline $8 \mathrm{cells}$ & $\begin{array}{l}\text { Occured within } 40-90 \text { minutes } \\
\text { after fertilization }\end{array}$ & $\begin{array}{l}\text { Occured within } 40-90 \text { minutes } \\
\text { after fertilization }\end{array}$ \\
\hline $16 \mathrm{sel}$ & $\begin{array}{l}\text { Terjadi dalam periode } 50-90 \\
\text { menit setelah fertilisasi }\end{array}$ & $\begin{array}{l}\text { Terjadi dalam periode } 50-90 \\
\text { menit setelah fertilisasi }\end{array}$ \\
\hline 16 cells & $\begin{array}{l}\text { Occured within } 50-90 \text { minutes } \\
\text { after fertilization }\end{array}$ & $\begin{array}{l}\text { Occured within } 50-90 \text { minutes } \\
\text { after fertilization }\end{array}$ \\
\hline $32 \mathrm{sel}$ & $\begin{array}{l}\text { Terjadi dalam periode } 80-110 \\
\text { menit setelah fertilisasi }\end{array}$ & $\begin{array}{l}\text { Terjadi dalam periode } 80-110 \\
\text { menit setelah fertilisasi }\end{array}$ \\
\hline 32 cells & $\begin{array}{l}\text { Occured within } 80-110 \text { minutes } \\
\text { after fertilization }\end{array}$ & $\begin{array}{l}\text { Occured within } 80-110 \text { minutes } \\
\text { after fertilization }\end{array}$ \\
\hline 64 sel & $\begin{array}{l}\text { Terjadi dalam periode } 90-130 \\
\text { menit setelah fertilisasi }\end{array}$ & $\begin{array}{l}\text { Terjadi dalam periode } 90-130 \\
\text { menit setelah fertilisasi }\end{array}$ \\
\hline 64 cells & $\begin{array}{l}\text { Occured within } 80-130 \text { minutes } \\
\text { after fertilization }\end{array}$ & $\begin{array}{l}\text { Occured within 90-130 minutes } \\
\text { after fertilization }\end{array}$ \\
\hline $128 \mathrm{sel}$ & $\begin{array}{l}\text { Terjadi dalam periode } 110-150 \\
\text { menit setelah fertilisasi }\end{array}$ & $\begin{array}{l}\text { Terjadi dalam periode } 110-150 \\
\text { menit setelah fertilisasi }\end{array}$ \\
\hline 128 cells & $\begin{array}{l}\text { Occured within 110-150 minutes } \\
\text { after fertilization }\end{array}$ & $\begin{array}{l}\text { Occured within 110-150 minutes } \\
\text { after fertilization }\end{array}$ \\
\hline Banyak sel (morula) & $\begin{array}{l}\text { Terjadi dalam periode } 130-220 \\
\text { menit setelah fertilisasi }\end{array}$ & $\begin{array}{l}\text { Terjadi dalam periode } 120-200 \\
\text { menit setelah fertilisasi }\end{array}$ \\
\hline Morula & $\begin{array}{l}\text { Occured within 130-220 minutes } \\
\text { after fertilization }\end{array}$ & $\begin{array}{l}\text { Occured within } 120-200 \text { minutes } \\
\text { after fertilization }\end{array}$ \\
\hline $\begin{array}{l}\text { Blastulasi (pembentukan } \\
\text { blastoderm) }\end{array}$ & $\begin{array}{l}\text { Terjadi dalam periode } 200-240 \\
\text { menit setelah fertilisasi }\end{array}$ & $\begin{array}{l}\text { Terjadi dalam periode } 190-220 \\
\text { menit setelah fertilisasi }\end{array}$ \\
\hline $\begin{array}{l}\text { Blastulasi (blastoderm } \\
\text { formation) }\end{array}$ & $\begin{array}{l}\text { Occured within 200-240 minutes } \\
\text { after fertilization }\end{array}$ & $\begin{array}{l}\text { Occured within 190-220 minutes } \\
\text { after fertilization }\end{array}$ \\
\hline $\begin{array}{l}\text { Gastrulasi (penutupan } \\
\text { kuning telur) }\end{array}$ & $\begin{array}{l}\text { Terjadi dalam periode } 230-450 \\
\text { menit setelah fertilisasi }\end{array}$ & $\begin{array}{l}\text { Terjadi dalam periode } 210-420 \\
\text { menit setelah fertilisasi }\end{array}$ \\
\hline $\begin{array}{l}\text { Gastrulasi (yolk } \\
\text { covering) }\end{array}$ & $\begin{array}{l}\text { Occured within } 230-450 \text { minutes } \\
\text { after fertilization }\end{array}$ & $\begin{array}{l}\text { Occured within } 210-420 \text { minutes } \\
\text { after fertilization }\end{array}$ \\
\hline
\end{tabular}


Tabel 1 Ianjutan (Table 1 continued)

\begin{tabular}{|c|c|c|}
\hline $\begin{array}{l}\text { Tahap } \\
\text { Stage }\end{array}$ & $\begin{array}{l}\text { Hibrida siamjambal } \\
P . \text { hypopthalmus XP. } \\
\text { djambal hybrid }\end{array}$ & $\begin{array}{c}\text { Hibrida siam-nasutus } \\
P . \text { hypophthalmus XP. } \\
\text { nasutus hybrid }\end{array}$ \\
\hline $\begin{array}{l}\text { Pembentukan bakal } \\
\text { kepala dan ekor }\end{array}$ & $\begin{array}{l}\text { Terjadi dalam periode } 430-490 \\
\text { menit setelah fertilisasi }\end{array}$ & $\begin{array}{l}\text { Terjadi dalam periode } 400-450 \\
\text { menit setelah fertilisasi }\end{array}$ \\
\hline $\begin{array}{l}\text { Head and tail buds } \\
\text { formation }\end{array}$ & $\begin{array}{l}\text { Occured within } 430-490 \text { minutes } \\
\text { after fertilization }\end{array}$ & $\begin{array}{l}\text { Occured within } 400-450 \text { minutes } \\
\text { after fertilization }\end{array}$ \\
\hline $\begin{array}{l}\text { Pembentukan kepala } \\
\text { dan ekor }\end{array}$ & $\begin{array}{l}\text { Terjadi dalam periode } 480-860 \\
\text { menit setelah fertilisasi }\end{array}$ & $\begin{array}{l}\text { Terjadi dalam periode } 430-800 \\
\text { menit setelah fertilisasi }\end{array}$ \\
\hline $\begin{array}{l}\text { Head and tail } \\
\text { formation }\end{array}$ & $\begin{array}{l}\text { Occured within } 480-860 \text { minutes } \\
\text { after fertilization }\end{array}$ & $\begin{array}{l}\text { Occured within } 430-800 \text { minutes } \\
\text { after fertilization }\end{array}$ \\
\hline $\begin{array}{l}\text { Pigmentasi kantung } \\
\text { kuning telur }\end{array}$ & $\begin{array}{l}\text { Terjadi mulai } 1.080 \text { menit setelah } \\
\text { fertilisasi }\end{array}$ & $\begin{array}{l}\text { Terjadi mulai } 1.000 \text { menit setelah } \\
\text { fertilisasi }\end{array}$ \\
\hline Yolk sac pigmentation & $\begin{array}{l}\text { Started to occur at } 1,080 \\
\text { minutes after fertilization }\end{array}$ & $\begin{array}{l}\text { Started to occur at } 1,000 \\
\text { minutes after fertilization }\end{array}$ \\
\hline Penetasan & $\begin{array}{l}\text { Terjadi dalam periode } 1.280- \\
1.600 \text { menit setelah fertilisasi }\end{array}$ & $\begin{array}{l}\text { Terjadi dalam periode } 1.200- \\
1.500 \text { menit setelah fertilisasi }\end{array}$ \\
\hline Hatching & $\begin{array}{l}\text { Occured within 1,280-1,600 } \\
\text { minutes after fertilization }\end{array}$ & $\begin{array}{l}\text { Occured within 1,200-1,500 } \\
\text { minutes after fertilization }\end{array}$ \\
\hline
\end{tabular}

adalah tahap perkembangan 2 sel, ditandai dengan terjadinya pembelahan mitosis sel tunggal menghasilkan dua buah sel yang berukuran lebih kecil dan sama (Gambar 2B). Pembelahan selanjutnya adalah tahap perkembangan 4 sel, ditandai dengan terjadinya pembelahan mitosis dari kedua sel menghasilkan empat buah sel (Gambar 2C). Tahap 8 sel ditandai dengan terjadinya pembelahan keempat sel menghasilkan delapan buah sel (Gambar 2D). Tahap- tahap perkembangan selanjutnya terjadi pembelahan- pembelahan sel secara mitosis menghasilkan sel-sel (blastomer) dengan jumlah dua kali lipat (duplikasi), sehingga terbentuk banyak sel berukuran kecil- kecil (Gambar 2E) dan dalam bentuk susunan yang bergerombol (morula) yang tampak lebih padat dibandingkan bagian kuning telur (Gambar 2F). Tahap perkembangan selanjutnya adalah blastulasi, ditandai dengan terjadinya invasi bagian kuning telur menghasilkan cincin germinal (germinal ring) dan sebagian kuning telur masih belum tertutupi blastoderm (blastomer) (Gambar 2G). Kemudian dilanjutkan dengan tahap gastrulasi, ditandai dengan terjadinya proses perluasan dan penutupan kuning telur oleh blastoderm ke arah blastopora (blastopore closure, epiboly) hingga seluruh bagian kuning telur telah tertutupi oleh blastoderm (Gambar $2 \mathrm{H}$ sampai
2K). Tahap perkembangan selanjutnya adalah terjadinya organogenesis, diawali dengan terbentuknya bakal kepala dan ekor (Gambar 2J dan 2K), pembentukan kepala, ekor, ruasruas tulang belakang, bakal mata, otolith, jantung, dan organ- organ lainnya (Gambar 2L dan $2 \mathrm{M}$ ), pigmentasi kantung kuning telur (Gambar 2N) dan penetasan (Gambar 2O) menghasilkan larva patin (Gambar 2P sampai 2T).

Diameter oosit dan telur di antara spesiesspesies ikan patin (Pangasiidae) menunjukkan adanya variasi. Oosit intraovarian patin siam yang dipergunakan dalam upaya peningkatan keberhasilan pemijahan buatan secara hormonal di Sukamandi (Indonesia) berdiameter $1,0 \pm 0,05 \mathrm{~mm}$ dan oosit terovulasi berukuran 1,04- 1,20 mm (Legendre et al., 1998b; 2000a), serupa dengan ukuran diameter oosit patin siam yang dipergunakan pada penelitian ini. Oosit intraovarian patin siam yang dipergunakan dalam upaya peningkatan keberhasilan pemijahan buatan secara hormonal di Delta Mekong (Vietnam) berdiameter $1,0 \mathrm{~mm}$, oosit terovulasi dan telur terfertilisasi berukuran 1,1-1,3 mm, sedangkan oosit intraovarian ikan patin $P$. bocourti berukuran $1,9 \mathrm{~mm}$, oosit terovulasi dan telur terfertilisasi berukuran 1,8-2,0 mm (Cacot, 1998; Cacot et al., 2002). Diameter telur terfertilisasi patin 

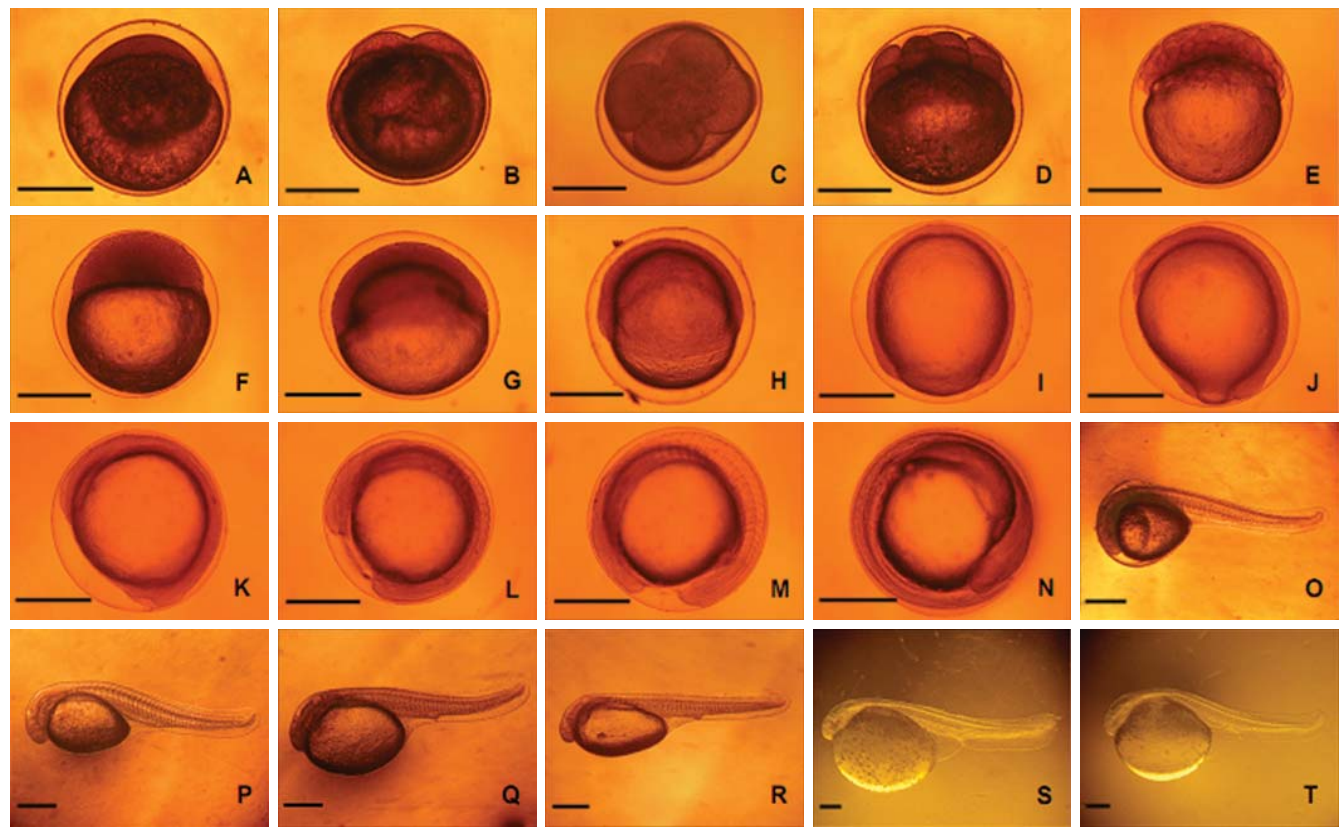

Gambar 2. Embriogenesis patin siam, jambal, nasutus, hibrida siam- jambal dan hibrida siam- nasutus. Proses perkembangan embrio $(A-N)$, penetasan $(O)$, larva patin hibrida siam- jambal $(P)$, hibrida siam- nasutus (Q), siam (R), jambal (S) dan nasutus (T) yang baru menetas (skala batang $=0,5 \mathrm{~mm}$ )

Figure 2. Embryogenesis of $\boldsymbol{P}$. hypophthalmus, P. djambal, P. nasutus, $\boldsymbol{P}$. hypophthalmus $X$ P. djambal hybrid, and $\boldsymbol{P}$. hypophthalmus $X$ P. nasutus hybrid. Embryonic development process (A-N), hatching $(O)$ and newly hatched larvae of $\boldsymbol{P}$. hypophthalmus $X \boldsymbol{P}$. djambal hybrid $(P), \boldsymbol{P}$. hypophthalmus $X \boldsymbol{P}$. nasutus hybrid $(Q)$, P. hypophthalmus (R), P. djambal $(S)$ and P. nasutus $(T)($ bar scale $=0.5 \mathrm{~mm})$

siam di Kazan (Rusia) berkisar 1,2- 1,8 mm (Islam, 2005). Diameter oosit terovulasi patin jambal yang dipergunakan dalam upaya pemijahan buatan secara hormonal pertama kali di Jambi (Indonesia) berkisar 1,8- 1,9 mm (Legendre et al., 1998a), serupa dengan diameter oosit patin jambal yang dipergunakan pada penelitian ini. Diameter oosit intraovarian ikan patin $P$. conchophilus di Delta Mekong berukuran 1,12- 1,20 mm (Xuan \& Liem, 1998). Diameter oosit terovulasi ikan patin yang dalam publikasi tersebut secara salah diidentifikasi sebagai $P$. pangasius di Sungai Musi (Indonesia) berkisar 1,4- 1,6 mm (Arifin, 1987) (lihat Tahapari et al., 2010a). Diameter oosit terovulasi ikan patin P. gigas di Chiang Mai (Thailand) berkisar 1,2- 1,4 mm (MengUmphan et al., 2006). Ukuran atau kisaran diameter oosit dan telur spesies patin siam di tempat yang berbeda tersebut juga menunjukkan adanya variasi. Perbedaan tersebut diduga karena perbedaan asal/ tempat (strain, sejarah), kondisi, ukuran, dan terutama perbedaan suplai pakan induk patin siam yang diberikan selama proses oogenesis.

Proses perkembangan embrio patin hibrida siam-jambal dan hibrida siam- nasutus pada penelitian ini secara umum serupa dengan perkembangan embrio spesies- spesies ikan Siluriformes (catfish) yang lain, misalnya ikan patin siam (Hardjamulia et al., 1981; Islam, 2005), ikan patin jambal (Slembrouck et al., 2003a), ikan patin nasutus (Tahapari et al., 2010a), ikan patin P. pangasius (Sarkar et al., 2002), ikan patin (yang secara salah diidentifikasi sebagai) P. pangasius (Arifin, 1987), ikan Mystus montanus (Bagridae) (Arockiaraj et al., 2003), ikan M. cavasius (Bagridae) (Rahman et al., 2004), ikan Heteropneustes fossilis (Clariidae) (Puvaneswari et al., 2009), ikan Pelteobagrus fulvidraco (Bagridae) (Wang et al., 2006) dan ikan- ikan Siluriformes yang 
Iain (di- review oleh Adriaens \& Vandewalle, 2003). Namun demikian, periode masingmasing tahap embriogenesis berbeda di antara spesies yang berbeda dan terutama sangat dipengaruhi oleh suhu air media inkubasi dan diameter oositnya (di- review oleh Fuiman, 2002).

Proses perkembangan embrio patin hibrida siam-jambal dan patin hibrida siam- nasutus relatif serupa, tetapi periode inkubasinya sedikit berbeda dan penetasan patin hibrida siam- nasutus terjadi sedikit lebih awal, yakni mulai terjadi 20 jam setelah fertilisasi dibandingkan 21 jam setelah fertilisasi pada suhu $28^{\circ} \mathrm{C}-29^{\circ} \mathrm{C}$. Proses perkembangan embrio kedua patin hibrida tersebut hampir serupa dengan proses perkembangan embrio patin siam sebagai induk betinanya (pada suhu media inkubasi y ang sama, patin siam mulai menetas 19 jam setelah fertilisasi), namun berbeda jauh jika dibandingkan dengan perkembangan embrio patin jambal dan nasutus sebagai induk jantannya (pada suhu media inkubasi yang sama, patin nasutus mulai menetas 30 jam setelah fertilisasi dan patin jambal 31 jam setelah fertilisasi). Hal tersebut tampaknya mengindikasikan bahwa proses perkembangan embrio patin-patin hibrida tersebut terutama lebih dipengaruhi oleh pengaruh maternal. Pola periode inkubasi kedua patin hibrida tersebut bersesuaian dengan pola periode inkubasi patin siam, jambal dan nasutus, yakni oosit patin siam yang difertilisasi dengan sperma patin nasutus (patin hibrida siam- nasutus) menetas lebih dahulu dibandingkan oosit patin siam yang difertilisasi dengan sperma patin jambal (patin hibrida siam-jambal), karena penetasan patin nasutus juga terjadi lebih dahulu dibandingkan patin jambal. Hal tersebut tampaknya mengindikasikan bahwa proses perkembangan embrio patin-patin hibrida tersebut juga dipengaruhi oleh pengaruh paternal.

Periode inkubasi telur di antara spesiesspesies ikan patin (Pangasiidae) menunjukkan adanya variasi. Boonbrahm (1968) melaporkan bahwa periode inkubasi patin siam di Thailand berkisar $27-33$ jam pada suhu inkubasi $26,5^{\circ} \mathrm{C}$ $31,0^{\circ} \mathrm{C}$. Hardjamulia et al. (1981) melaporkan bahwa penetasan larva patin siam di Cibalagung (Indonesia) terjadi 29- 31 jam setelah fertilisasi pada suhu $24,0^{\circ} \mathrm{C}-26,5^{\circ} \mathrm{C}$. Hasil penelitian Cacot (1998) menunjukkan bahwa penetasan larva patin siam di Delta Mekong (Vietnam) pada suhu inkubasi $27,7^{\circ} \mathrm{C}$ - $31,0^{\circ} \mathrm{C}$ terjadi $19,33-22,67$ jam setelah fertilisasi dan pada suhu inkubasi $29^{\circ} \mathrm{C}-30^{\circ} \mathrm{C}$ terjadi 19- 22 jam setelah fertilisasi. Kristanto et al. (1998) menyatakan bahwa periode inkubasi patin siam di Sukamandi (Indonesia) berkisar $19-20$ jam pada suhu inkubasi $28,5^{\circ} \mathrm{C}$ $29,5^{\circ} \mathrm{C}$. Penetasan larva patin siam di Bengal (India) dilaporkan terjadi 24 jam setelah fertilisasi pada suhu inkubasi $30-32^{\circ} \mathrm{C}$ (Chattopadhyay et al., 2002). Di Kazan (Rusia), periode inkubasi patin siam dilaporkan berkisar 24- 36 jam pada suhu inkubasi $20^{\circ} \mathrm{C}$ $30^{\circ} \mathrm{C}$ (Islam, 2005). Penetasan larva ikan patin $P$. gigas dilaporkan terjadi 42 jam setelah fertilisasi pada suhu inkubasi $25^{\circ} \mathrm{C}$ (Mattson et al., 2002). Penetasan larva ikan patin $P$. bocourti dilaporkan terjadi 25 - 30 jam setelah fertilisasi pada suhu $26,3^{\circ} \mathrm{C}-30,7^{\circ} \mathrm{C}$ (Cacot et al., 2002). Periode inkubasi ikan patin $P$. djambal berkisar 29-36 jam pada suhu inkubasi $27^{\circ} \mathrm{C}-30^{\circ} \mathrm{C}$ (Legendre et al., 1998a). Penetasan larva ikan patin (yang secara salah diidentifikasi sebagai) $P$. pangasius di Sungai Musi mulai terjadi 28 jam setelah fertilisasi pada suhu inkubasi $26^{\circ} \mathrm{C}-28^{\circ} \mathrm{C}$ (Arifin, 1987). Penetasan larva ikan patin $P$. pangasius di Mymensingh (Bangladesh) terjadi 28- 32 jam setelah fertilisasi pada suhu inkubasi $26^{\circ} \mathrm{C}$ $28^{\circ} \mathrm{C}$ (Khan \& Mollah, 2004), sedangkan di Bengal (India) terjadi 25 jam setelah fertilisasi pada suhu inkubasi $30^{\circ} \mathrm{C}-31^{\circ} \mathrm{C}$ (Sarkar et al., 2006).

Periode inkubasi di antara ikan-ikan Siluriformes hibrida juga menunjukkan adanya perbedaan. Lenormand et al. (1998) dalam penelitian hibridisasi antara ikan lele Clarias gariepinus dengan $C$. meladerma (Clariidae) secara resiprokal menyatakan bahwa pada suhu inkubasi yang sama $\left(27^{\circ} \mathrm{C}\right)$, periode inkubasi hibrida- hibridanya bersifat diantara kedua induk tetuanya (terjadi 20-24 jam setelah fertilisasi pada C. gariepinus dan 2936 jam setelah fertilisasi pada C. meladerma), yakni berkisar 22- 26 jam setelah fertilisasi pada hibrida C. gariepinus X C. meladerma dan 2631 jam setelah fertilisasi pada hibrida $C$. meladerma X C. gariepinus. Haniffa et al. (2009) dalam penelitian hibridisasi antara betina ikan $M$. gulio dengan jantan ikan $M$. montanus (Bagridae) menyatakan bahwa proses perkembangan embrionya sedikit lebih lambat dibandingkan perkembangan embrio induk tetuanya dengan lama inkubasi yang sedikit lebih lama (24 jam) dibandingkan induk tetuanya (22 jam). Legendre et al. (1992) menyatakan bahwa periode inkubasi ikan 
hibrida hasil hibridisasi antara ikan $C$. gariepinus dengan Heterobranchus longifilis (Clariidae) secara resiprokal relatif sama dengan induk tetuanya (24- 25 jam setelah fertilisasi pada suhu $27^{\circ} \mathrm{C}-29^{\circ} \mathrm{C}$ ).

\section{Perkembangan Larva}

Hasil pengamatan perkembangan ontogeni morfologis (morfogenesis) larva patin hibrida siam- jambal sampai umur 10 hari pada penelitian ini disajikan pada Gambar 3 dan patin hibrida siam- nasutus pada Gambar 4.

Proses perkembangan larva patin hibrida siam-jambal relatif serupa dengan patin hibrida siam- nasutus. Larva patin hibrida siam- jambal yang baru menetas rata- rata berukuran panjang

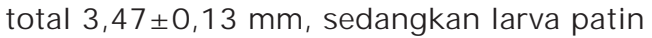
hibrida siam- nasutus rata- rata berukuran panjang total 3,34 $\pm 0,14 \mathrm{~mm}$ (Tabel 2). Badan larva kedua patin hibrida tersebut tampak bersegmen, transparan dan belum memiliki pigmen melanofora, kecuali sedikit pada bagian ventrolateral kantung kuning telur. Sirip sebagai alat pergerakannya baru berupa bakal sirip ekor (caudal fin fold) dan bakal sirip anal (anal fin fold) yang masih menyatu. Mulutnya belum membuka. Saluran pencernaan berupa saluran pendek (alimentary canal) dari ujung belakang kantung kuning telur sampai pangkal bakal sirip anal (Gambar $3 A$ dan 4A).

Bakal sirip ekor dan bakal sirip anal yang masih menyatu merupakan organ pergerakan awal larva patin hibrida siam- jambal dan hibrida siam- nasutus yang baru menetas. Sirip lemak (adipose fin) dan sirip anal larva kedua patin hibrida tersebut mulai terbentuk 24 jam setelah menetas (Gambar 3C dan 4C). Jari-
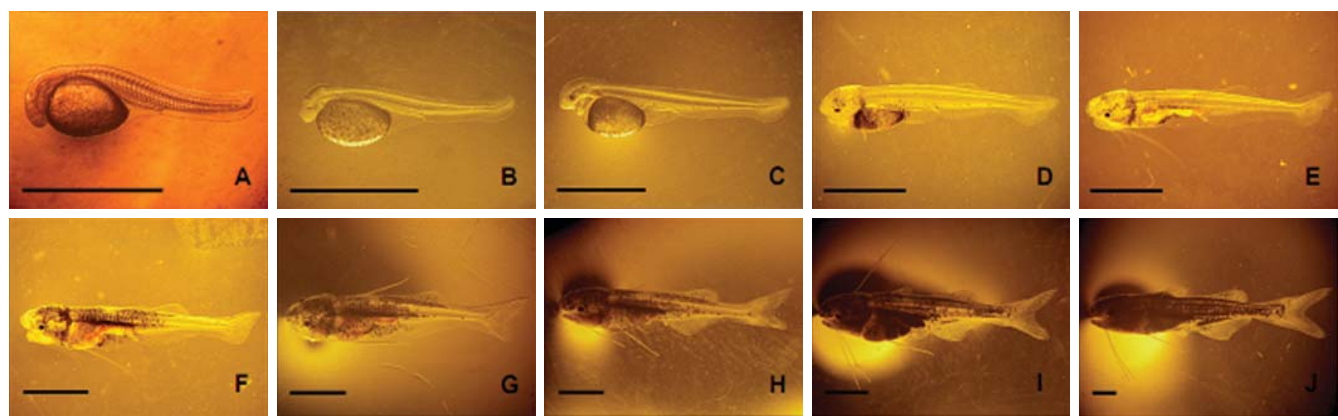

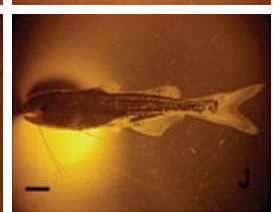

Gambar 3. Perkembangan morfologis larva patin hibrida siam- jambal sampai umur 10 hari (skala batang $=2 \mathrm{~mm}$ )

Figure 3. Morphological development of P. hypophthalmus X P. djambal hybrid larvae during 10 days post hatching (bar scale $=2 \mathrm{~mm}$ )
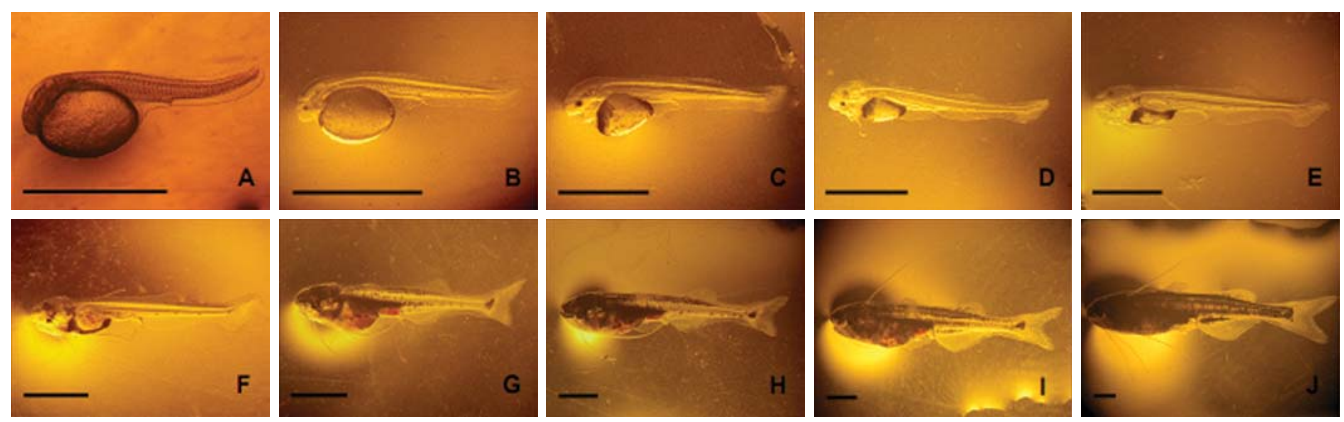

Gambar 4. Perkembangan morfologis larva patin hibrida siam- nasutus sampai umur 10 hari (skala batang $=2 \mathrm{~mm}$ )

Figure 4. Morphological development of $\boldsymbol{P}$. hypophthalmus $X$ P. nasutus hybrid larvae during 10 days post hatching (bar scale $=2 \mathrm{~mm}$ ) 
jari sirip ekor (caudal fin rays) larva kedua patin hibrida tersebut mulai terbentuk pada umur 48 jam (Gambar 3E dan 4F) dan mulai bersegmen pada umur 78 jam (Gambar $3 G$ dan $4 G)$. Bagian bawah sirip ekor mulai terbentuk (memanjang) pada umur 60 jam, sehingga sirip ekor (caudal fin) mulai bercagak (forked) (Gambar 3F dan 4G) dan panjang bagian atas sirip ekor hampir sama dengan bagian bawahnya pada saat larva patin hibrida siamjambal berumur 110 jam dan umur 120 jam pada larva patin hibrida siam- nasutus (Gambar 3H dan $4 \mathrm{H}$ ). Bakal sirip dada (pectoral fins) larva patin hibrida siam- jambal mulai terbentuk pada umur 60 jam, sedangkan pada larva patin hibrida siam- nasutus mulai terbentuk pada umur 72 jam. Bakal sirip punggung (dorsal fin) larva kedua patin hibrida tersebut mulai terbentuk pada umur 60 jam (Gambar 3D dan 4G). Jari- jari sirip punggung (dorsal fin rays) larva patin hibrida siam- nautus mulai terbentuk pada umur 110 jam (Gambar 4I) dan duri sirip punggung (dorsal spine) terbentuk pada umur 144 jam (Gambar 4l), sedangkan duri sirip punggung larva patin hibrida siam- jambal mulai terbentuk pada umur 114 jam (Gambar 3I). Bakal sirip perut (ventral fins) larva kedua patin hibrida tersebut mulai terbentuk pada umur 110 jam (Gambar 3H dan 4H). Jari- jari sirip anal (anal fin rays) larva kedua patin hibrida tersebut mulai terbentuk pada umur 72 jam
(Gambar 3F dan 4F) dan mulai bersegmen pada umur 78 jam (Gambar 3G dan 4G). Sirip anal (anal fin) mulai terpisah dari sirip ekor pada umur 144 jam dan pada larva patin hibrida siamjambal benar- benar terpisah pada umur 192 jam, sedangkan pada larva patin hibrida siamnasutus benar- benar terpisah pada umur 180 jam (Gambar 3I dan 4I). Sirip preanal (preanal fin fold, abdominal keel) yang ada sejak kedua larva patin hibrida tersebut menetas mulai mengalami rudimenter sehingga menjadi tidak ada lagi pada umur 240 jam (Gambar 3J dan 4J).

Kantung kuning telur larva patin hibrida siam-jambal yang baru menetas rata-rata berukuran $0,42 \pm 0,08 \mathrm{~mm}^{3}$, sedangkan pada larva patin hibrida siam- nasutus rata- rata berukuran $0,71 \pm 0,28 \mathrm{~mm}^{3}$. Volume kantung kuning telur larva patin hibrida siam-jambal mengalami penyerapan sekitar $50 \%$ pada umur 30 jam, dan relatif habis terserap pada umur 60 jam, sedangkan pada larva patin hibrida siam- nasutus mengalami penyerapan sekitar $50 \%$ pada umur 24 jam, dan relatif habis terserap pada umur 54 jam (Gambar 5).

Pigmentasi pada mata larva patin hibrida siam- jambal dan hibrida siam- nasutus mulai terjadi 3 jam setelah menetas (Gambar 3B dan 4B). Pigmentasi juga sedikit mulai terjadi pada ekor bagian depan, Badan bagian depan dan kepala pada larva patin hibrida siam-jambal

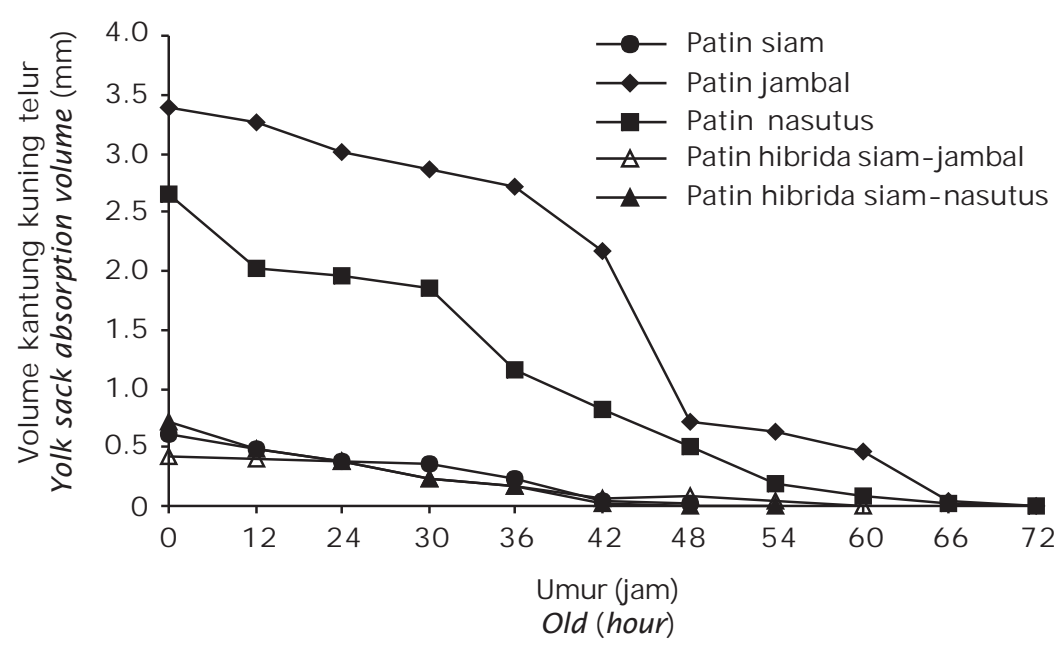

Gambar 5. Penyerapan kantung kuning telur larva patin siam, jambal, nasutus, hibrida siam- jambal, dan hibrida siam- nasutus

Figure 5 Yolk sac absorption of $\boldsymbol{P}$. hypophthalmus, $\boldsymbol{P}$. djambal, $\boldsymbol{P}$. nasutus, $\boldsymbol{P}$. hypophthalmus $X \boldsymbol{P}$. djambal hybrid and $\boldsymbol{P}$. hypophthalmus $X$ P. nasutus hybrid larvae. 
umur 24 jam dan umur 30 jam pada larva patin hibrida siam- nasutus (Gambar 3C dan 4D). Pigmentasi tersebut dengan lambat terus meluas ke arah belakang (Gambar 3D, 3E dan 4E) hingga pada saat berumur 72 jam pada larva patin hibrida siam- jambal dan umur 60 jam pada larva patin hibrida siam- nasutus sebagian badan bagian depan mulai dari kepala sampai bagian dorsoventral telah berpigmen (Gambar 3F dan 4G), dan terus meluas hingga mencapai batang ekor (caudal peduncle) (Gambar 3G- 3J dan $4 \mathrm{H}-4 \mathrm{~J}$ ). Pigmentasi pada pangkal batang ekor larva patin hibrida siam- nasutus yang berupa noktah hitam mulai terjadi pada umur 60 jam (Gambar 4G), sedangkan larva patin hibrida siam- jambal tidak memilikinya.

Rahang atas mulut larva patin hibrida siam- jambal dan hibrida siam- nasutus mulai terbentuk 8 jam setelah menetas (Gambar 3B dan 4B). Kedua rahang terbentuk 24 jam setelah menetas dengan mulut yang selalu terbuka (Gambar 3C dan 4C). Gigi- gigi rahang atas larva kedua patin hibrida tersebut mulai terbentuk 24 jam setelah menetas, selanjutnya gigi- gigi rahang bawah mulai terbentuk 30 jam setelah menetas. Mulut larva kedua patin hibrida tersebut mulai bergerak membuka dan menutup pada umur 30 jam (Gambar 3D dan 4D), dan aktif membuka dan menutup pada umur 36 jam, tetapi respons terhadap pakan alami (nauplii Artemia sp.) masih rendah. Larva patin hibrida siam-jambal mulai merespon pakan alami dengan baik pada umur 48 jam (Gambar 3E), sedangkan larva patin hibrida siam- nasutus pada umur 42 jam (Gambar 4F).

Sungut rahang atas (maxillary barbels) larva patin hibrida siam- jambal maupun hibrida siam- nasutus mulai tumbuh pada umur 24 jam (Gambar 3C dan 4C). Sungut rahang bawah (mandibulary barbels) larva kedua patin hibrida tersebut mulai tumbuh pada umur 30 jam dan sungut rahang atas semakin memanjang (Gambar 3D dan 4D).

Saluran pencernaan yang awalnya berupa saluran pendek, pada saat larva patin hibrida siam- jambal berumur 24 jam dan larva patin hibrida siam- nasutus umur 30 jam mulai membesar pada bagian anteriornya dan mulai berdiferensiasi menjadi bakal lambung dan usus pendek (Gambar 3C, 3D, 4D, dan 4E). Selanjutnya, lambung larva kedua patin hibrida tersebut mulai terbentuk dan berfungsi pada umur 48 jam, berukuran 0,013-0,023 mm $\mathrm{mm}^{3}$ dengan usus sepanjang 1,12- 1,19 mm pada larva patin hibrida siam-jambal dan berukuran
0,045- 0,092 $\mathrm{mm}^{3}$ dengan usus sepanjang 1,12$1,26 \mathrm{~mm}$ pada larva patin hibrida siam- nasutus (Gambar 3E dan 4F).

Perkembangan ontogeni morfologis larva patin hibrida siam- jambal dan hibrida siamnasutus pada penelitian ini secara umum serupa dengan perkembangan larva patin siam (Islam, 2005), patin jambal (Slembrouck et al., 2003a) dan patin nasutus (Tahapari et al., 2010a), maupun larva ikan M. punctatus (Bagridae) (Ramanathan et al., 1985), larva ikan M. macropterus (Bagridae) (Wang et al., 1992), larva ikan M. montanus (Bagridae) (Arockiaraj et al., 2003), larva ikan M. cavasius (Bagridae (Rahman et al., 2004), larva ikan Pseudobagrus ichikawai (Bagridae) (Watanabe, 1994), larva ikan $\mathrm{H}$. fossilis (Clariidae) (Puvaneswari et al., 2009), serta larva ikan- ikan Siluriformes yang lain (direview oleh Adriaens \& Vandewalle, 2003) dan juga larva ikan- ikan Teleostei yang Iain (direview oleh Blaxter, 1988; Fuiman, 2002). Secara umum, perkembangan sirip- sirip tunggal terjadi lebih awal daripada sirip- sirip berpasangan, sirip perut berkembang paling akhir dan kantung kuning telur terserap dalam dua hingga empat hari setelah menetas.

Identifikasi spesies-spesies patin berukuran dewasa secara morfologis telah diberikan secara jelas dan detail, tetapi identifikasi pada ikan-ikan patin yang berukuran kecil dan larva sulit dilakukan dan hampir seluruh peneliti mengalami kesulitan mengenali anak ikan dari induknya karena adanya kemiripan morfologis (Roberts \& Vidthayanon, 1991; Gustiano, 2009; Sriphairoj et al., 2010). Pigmentasi pada tahap awal perkembangan larva merupakan salah satu kunci identifikasi larva ikan patin karena pola pigmentasi larva yang baru menetas diantara jenis patin yang berbeda menunjukkan adanya perbedaan. Larva patin siam yang baru menetas hampir tidak memiliki pigmen, kecuali sedikit pada bagian anterior dan posterior kantung kuning telur (Gambar 2R). Larva patin jambal dan patin nasutus yang baru menetas memiliki pola pigmen yang serupa, yakni hampir seluruh bagian kantung kuning telur memiliki pigmen, tetapi pigmentasi pada larva patin jambal lebih pekat dan relatif merata (Gambar 2S dan 2T). Larva patin hibrida siamjambal yang baru menetas memiliki pigmen yang pekat pada bagian anterior dan posterior serta agak pekat pada seluruh bagian kantung kuning telur (Gambar 2P). Larva patin hibrida siam-nasutus yang baru menetas 
memiliki pigmen yang pekat pada bagian anterior dan posterior serta sedikit pada bagian ventral kantung kuning telur (Gambar 2Q).

Pada periode perkembangan selanjutnya, pola pigmentasi tersebut masih dapat dipergunakan sebagai kunci identifikasi larva patin. Larva patin siam pada perkembangan pigmentasi selanjutnya tetap hanya memiliki pigmen yang tidak pekat hingga ketika telah mulai memiliki kelengkapan organ menyerupai ikan dewasa (umur 228 jam) pigmentasinya tetap tidak pekat dan tidak merata dengan membentuk pola garis-garis horizontal sehingga patin siam juga dikenal sebagai striped catfish (Gambar 6A). Larva patin jambal dan nasutus pada perkembangan pigmentasi selanjutnya hingga ketika telah mulai memiliki kelengkapan organ menyerupai ikan dewasa (patin nasutus umur 168 jam dan patin jambal umur 132 jam) juga tetap menunjukkan pola yang serupa, yakni memiliki pigmen yang pekat dan merata pada sebagian tubuh bagian depan. Tetapi, pigmentasi larva patin jambal telah mencapai pangkal sirip lemak dan sirip anal, sedangkan pigmentasi larva patin nasutus belum mencapai sirip lemak dan sirip anal. Selain itu, larva patin nasutus telah memiliki pigmen yang berupa noktah hitam pada batang ekornya, sehingga dapat dibedakan dari larva patin jambal (Gambar 6B dan 6C). Larva patin hibrida siam- jambal dan hibrida siam- nasutus pada perkembangan pigmentasi selanjutnya hingga ketika telah memiliki kelengkapan organ menyerupai ikan dewasa (umur 180 jam) juga tetap menunjukkan pola yang serupa, yakni memiliki pigmen yang cukup pekat dan relatif merata pada seluruh tubuh, mulai dari kepala hingga batang ekor (Gambar 3J dan 4J). Namun demikian, larva patin hibrida siamnasutus dapat dibedakan dari larva patin hibrida siam- jambal berdasarkan keberadaan pigmentasi yang berupa noktah hitam pada batang ekor larva patin hibrida siam- nasutus pada saat berumur 60- 168 jam (Gambar 4G sampai 4I), yakni pada periode ketika bagian ekor kedua larva patin hibrida tersebut belum berpigmen sampai memiliki sedikit pigmen. Tetapi, ketika pigmentasi telah mencapai bagian batang ekor (mulai umur 180 jam), maka larva kedua patin hibrida tersebut tampak telah memiliki pola pigmen yang serupa, sehingga sulit dibedakan (Gambar 3J dan 4J).

Hasil pengamatan Islam (2005) menunjukkan bahwa larva patin siam yang baru menetas hampir tidak memiliki pigmen. Larva ikan patin $P$. bocourti yang baru menetas memiliki pigmentasi berupa bintik- bintik hitam pada kantung kuning telur (Cacot et al., 2002), serupa dengan larva patin jambal (Slembrouck et al., 2003). Larva ikan patin (yang dalam publikasi tersebut secara salah diidentifikasi sebagai) P. pangasius di Sungai Musi yang baru menetas berwarna kehitaman karena telah memiliki pigmen (Arifin, 1987), sedangkan larva ikan patin $P$. pangasius (yang sebenarnya) yang baru menetas di Mymensingh tampak transparan dan tidak memiliki pigmen (Khan \& Mollah, 2004).

Hassan et al. (2011) melaporkan telah melakukan penelitian hibridisasi antara patin siam ( $P$. hypophthalmus) dengan patin nasutus (P. nasutus). Tetapi, deskripsi larvanya berbeda dari karakteristik larva patin hibrida siamnasutus dalam penelitian ini dan bersesuaian dengan karakteristik larva patin hibrida siamjambal. Larva patin hibrida dalam publikasi tersebut tidak memiliki pigmen yang berupa noktah hitam pada pangkal batang ekor yang merupakan karakteristik khas larva patin hibrida siam- nasutus maupun patin nasutus. Dengan demikian, spesies patin yang dalam
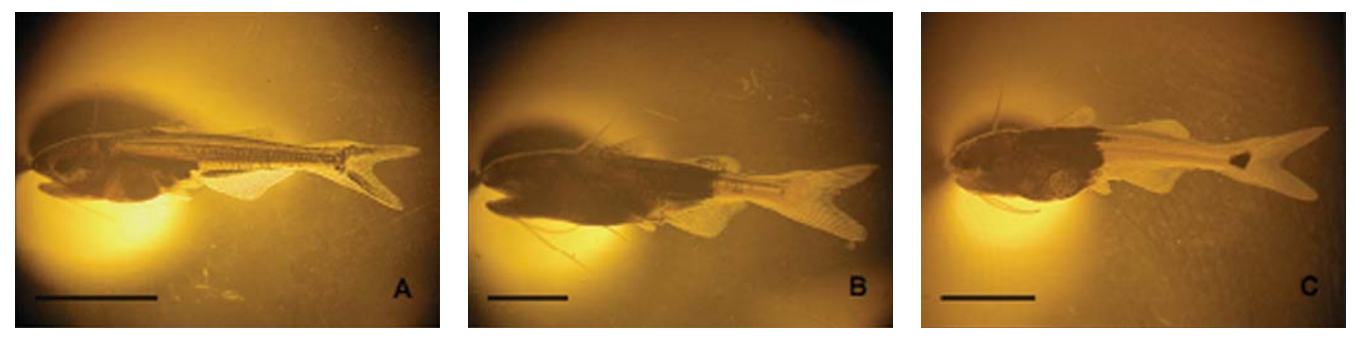

Gambar 6. Larva patin siam (A), jambal (B) dan nasutus (C) umur 10 hari (skala batang $=5 \mathrm{~mm}$ )

Figure 6. Larvae of P. hypophthalmus (A), P. djambal (B) and P. nasutus (C) at 10 days old (bar scale $=5 \mathrm{~mm}$ ) 
publikasi tersebut disebut sebagai $P$. nasutus merupakan suatu kesalahan identifikasi, karena spesies patin tersebut seharusnya adalah $P$. djambal. Hal ini juga diperkuat oleh kenyataan bahwa tempat pelaksanaan penelitian tersebut sama dengan penelitian ini (di LRPTBPAT, Sukamandi), tetapi di tempat tersebut pada saat itu belum dilakukan penelitian hibridisasi patin nasutus, sedangkan penelitian hibridisasi patin jambal telah sering dilakukan (pengamatan pribadi).

Jumlah jari-jari sirip perut banyak dipergunakan untuk mengidentifikasi spesiesspesies patin (Gustiano \& Pouyaud, 2005; 2007; 2008) maupun patin-patin hibrida (Gustiano, 2004; Gustiano \& Kristanto, 2007). Jumlah jari- jari sirip perut tersebut telah dapat dipergunakan sebagai kunci identifikasi sejak larva melalui pengamatan secara mikroskopis. Jari- jari sirip perut larva patin hibrida siamjambal dan hibrida siam- nasutus berjumlah tujuh, bersifat di antara (intermediate) kedua induk tetuanya, yakni berjumlah delapan pada larva patin siam dan berjumlah enam pada larva patin jambal maupun nasutus. Jumlah jari- jari sirip perut larva patin hibrida siam- jambal dan hibrida siam- nasutus tersebut sama dengan jumlah jari- jari sirip perut yang dilaporkan pada patin hibrida hasil hibridisasi antara patin siam dengan patin jambal yang telah berukuran besar (Gustiano, 2004; LRPTBPAT, 2006; Gustiano \& Kristanto, 2007).

\section{Heterosis pada Tahap Larva}

Ukuran panjang total larva patin patin siam, jambal, nasutus, hibrida siam-jambal dan hibrida siam- nasutus yang baru menetas dan umur 10 hari berdasarkan pengukuran secara mikroskopis disajikan pada Tabel 2. Perkembangan panjang total larva patin siam, jambal, nasutus, hibrida siam-jambal dan hibrida siam- nasutus selama 10 hari masa pemeliharaan larva berdasarkan pengukuran secara mikroskopis disajikan pada Gambar 7.

Heterosis karakter pertumbuhan larva sampai berumur 10 hari berdasarkan pertambahan panjang total rata-rata pada penelitian ini menunjukkan bahwa larva patin hibrida siam- nasutus memiliki pertambahan panjang total rata- rata $21,47 \%$ lebih tinggi daripada larva patin siam dan $18,95 \%$ lebih tinggi daripada larva patin nasutus serta $20,20 \%$ lebih tinggi daripada rata- rata larva

Tabel 2. Ukuran panjang total larva patin siam, jambal, nasutus, hibrida siam- jambal dan hibrida siam- nasutus yang baru menetas dan umur 10 hari $(n=30$ ekor)

Table 2. Total length of newly hatched P. hypophthalmus, P. djambal, P. nasutus, $\boldsymbol{P}$.

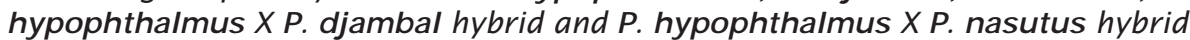
larvae and 10 days old larvae $(n=30$ larvae)

\begin{tabular}{|c|c|c|c|c|}
\hline \multirow{3}{*}{$\begin{array}{l}\text { Larva ikan } \\
\text { Larvae }\end{array}$} & \multicolumn{4}{|c|}{$\begin{array}{c}\text { Panjang total } \\
\text { Total length (mm) }\end{array}$} \\
\hline & \multicolumn{2}{|c|}{$\begin{array}{c}\text { Menetas } \\
\text { At hatching }\end{array}$} & \multicolumn{2}{|c|}{$\begin{array}{l}\text { Umur } 10 \text { hari } \\
\text { At } 10 \text { days old }\end{array}$} \\
\hline & $\begin{array}{c}\text { Kisaran } \\
\text { Range }\end{array}$ & $\begin{array}{l}\text { Rata-rata } \\
\text { Mean }\end{array}$ & $\begin{array}{c}\text { Kisaran } \\
\text { Range }\end{array}$ & $\begin{array}{l}\text { Rata-rata } \\
\text { Mean }\end{array}$ \\
\hline Patin siam & $3.13-3.25$ & $3.18 \pm 0.08$ & $15.73-18.27$ & $16.98 \pm 0.81$ \\
\hline \multicolumn{5}{|l|}{ P. hypophthalmus } \\
\hline Patin jambal & $4.90-5.25$ & $5.08 \pm 0.13$ & $19.87-26.00$ & $22.12 \pm 1.34$ \\
\hline \multicolumn{5}{|l|}{ P. djambal } \\
\hline Patin nasutus & $4.80-5.10$ & $4.90 \pm 0.08$ & $17.73-21.27$ & $18.98 \pm 0.44$ \\
\hline \multicolumn{5}{|l|}{ P. nasutus } \\
\hline Patin hibrida siam-jambal & $3.25-3.63$ & $3.47 \pm 0.13$ & $17.47-19.33$ & $18.25 \pm 0.54$ \\
\hline \multicolumn{5}{|l|}{ P. hypophthalmus $X$ P. djambal hybrid } \\
\hline Patin hibrida siam-nasutus & $3.25-3.63$ & $3.34 \pm 0.14$ & $18.40-22.80$ & $20.10 \pm 1.21$ \\
\hline P. hypophthalmus $X$ P. nasutus hybrid & & & & \\
\hline
\end{tabular}




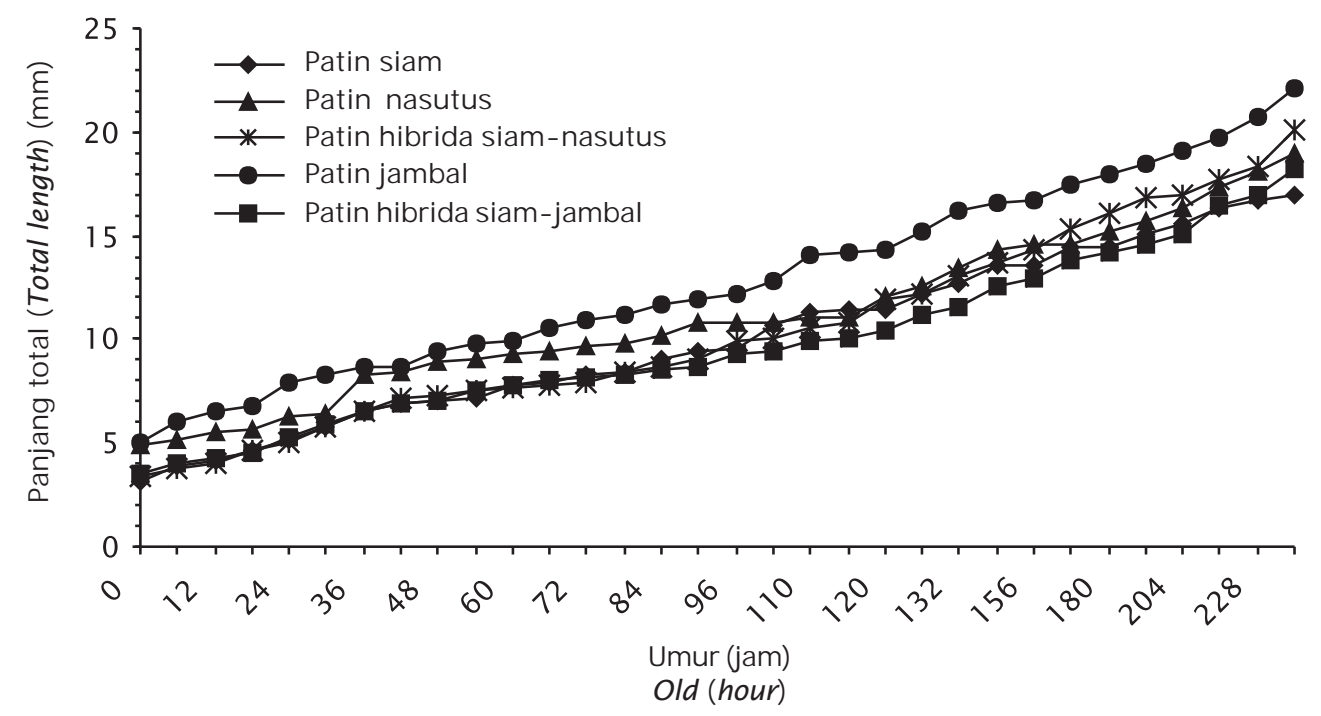

Gambar 7. Perkembangan panjang total larva patin siam, jambal, nasutus, hibrida siam- jambal, dan hibrida siam- nasutus selama 10 hari masa pemeliharaan

Figure 7. Total length development of P. hypophthalmus, P. djambal, P. nasutus, $\boldsymbol{P}$. hypophthalmus $X$ P. djambal hybrid and $\boldsymbol{P}$. hypophthalmus $X$ P. nasutus hybrid larvae

patin siam dan nasutus, sedangkan larva patin hibrida siam-jambal memiliki pertambahan panjang total rata- rata $7,16 \%$ lebih tinggi daripada larva patin siam, tetapi 13,30\%lebih rendah daripada larva patin jambal dan $4,15 \%$ lebih rendah daripada rata- rata larva patin siam dan jambal. Tabel 2 juga menunjukkan bahwa pertambahan panjang total larva patin hibrida siam-nasutus selama 10 hari masa pemeliharaan $(16,76 \mathrm{~mm})$ relatif lebih tinggi daripada larva patin hibrida siam- jambal (14,78 mm). Namun demikian, Gustiano \& Kristanto (2007) melaporkan bahwa patin hibrida hasil hibridisasi antara betina patin siam dengan jantan patin jambal pada tahap pembesaran memiliki keragaan laju pertumbuhan yang lebih bagus daripada kedua induk tetuanya, mengindikasikan adanya heterosis yang positif. Legendre et al. (1992) melaporkan bahwa ikan hibrida hasil hibridisasi antara betina ikan $\mathrm{H}$. fossilis dengan jantan ikan $\mathrm{C}$. gariepinus (Clariidae) menunjukkan keragaan pertumbuhan yang lebih bagus daripada kedua induk tetuanya selama 254 hari dalam tahap pembesaran. Namun demikian, hasil penelitian Ataguba et al. (2009) menunjukkan bahwa keragaan pertumbuhan larva hibrida hasil persilangan antara betina ikan $H$. fossilis dengan jantan C. gariepinus selama 15 hari masa pemeliharaan pada kondisi hatcheri tidak lebih bagus daripada kedua induk tetuanya. Hasil analisis efek heterosis ikan-ikan hibrida tersebut menunjukkan bahwa ikan hibrida dapat memiliki keragaan pertumbuhan yang berbeda pada tahap pemeliharaan yang berbeda, sehingga analisis efek heterosis perlu dilakukan secara menyeluruh pada berbagai tahap pemeliharaan.

\section{KESIMPULAN}

Berdasarkan hasil penelitian identifikasi perkembangan embrio dan larva patin hibrida siam- jambal dan hibrida siam- nasutus selama 10 hari masa pemeliharaan menunjukkan bahwa:

- Periode perkembangan embrio dan larva patin hibrida siam- jambal dan hibrida siamnasutus hampir sama dengan patin siam sebagai induk betinanya, sedangkan perkembangan embrio patin jambal dan nasutus berlangsung lebih lama dengan perkembangan ontogeni morfologis larva yang lebih cepat.

- Larva patin hibrida siam- nasutus memiliki keragaan pertumbuhan yang lebih bagus daripada kedua induk tetuanya (memiliki heterosis yang positif), sedangkan larva 
patin hibrida siam- jambal hanya memiliki heterosis yang positif terhadap patin siam sebagai induk betinanya, tetapi memiliki heterosis yang negatif terhadap patin jambal sebagai induk jantannya maupun terhadap rata- rata patin siam dan jambal.

\section{UCAPAN TERIMA KASIH}

Penulis menyampaikan rasa terima kasih dan penghargaan yang sebesar-besarnya kepada Kamlawi, Tatang, dan kawan- kawan teknisi komoditas riset patin Loka Riset Pemuliaan dan Teknologi Budidaya Perikanan Air Tawar, atas bantuan teknisnya selama kegiatan pemilihan induk, pemijahan buatan dan pemeliharaan larva.

\section{DAFTAR ACUAN}

Adriaens, D. \& Vandewalle, P. 2003. Embryonic and larval development in catfishes. In: G. Arratia, B. Kapoor, M. Chardon and R. Diogo (eds.). Catfishes. Science Publisher, Inc. USA, p. 639-666.

Arifin, Z. 1987. Pembenihan ikan patin (Pangasius pangasius) dengan rangsangan hormon. Buletin Penelitian Perikanan Darat, 6: 42- 47.

Arockiaraj, A.J., Haniffa, M.A., Seetharaman, S., $\&$ Singh, S.P. 2003. Early development of a threatened freshwater catfish, Mystus montanus (Jerdon). Acta Zoologica Taiwanica, 14(1): 23- 32.

Ataguba, G.A., Annune, P.A., \& Ogbe, F.G. 2009. Induced breeding and early growth of progeny from crosses between two African clariid fishes, Clarias gariepinus (Burchell) and Heterobranchus longifilis under hatchery conditions. J. of Applied Biosciences, 14: 755- 760.

Blaxter, J.H.S. 1988. Patern and variety in development. In: W.S. Hoar and D.J. Randall (Eds.). Fish Physiology VolumeXI, The Physiology of Developing Fish Part A, Eggs and Larvae. Academic Press, Inc. San Diego, p. 1-58.

Boonbrahm, M. 1968. Induced spawning by pituitary hormones injection of pondreared fishes. Indo- Pacific Fisheries Council Proceedings 13th Session, Section II Technical Papers, Brisbane- Queensland, Australia, 14- 25 October 1968, p. 162- 170.

Cacot, P. 1998. Description of the sexual cycle related to the environment and set up of the artificial propagation in Pangasius bocourti (Sauvage, 1880) and Pangasius hypophthalmus (Sauvage, 1878) reared in floating cages and ponds in the Mekong Delta. In: M. Legendre and A. Parisele (Eds.). The Biological Diversity and Aquaculture of Clariid and Pangasiid Catfishes in SouthEast Asia. Proceeding of The Mid- Term Workshop of the Catfish Asia Project, 11- 15 May 1998. Cantho- Vietnam, p. 71- 89.

Cacot, P., Legendre, M., Dan, T.Q., Tung, L.T., Liem, P.T., Mariojouls, C., \& Lazard, J. 2002. Induced ovulation of Pangasius bocourti (Sauvage, 1880) with a progressive hCG treatment. Aquaculture, 213: 199- 206.

Chattopadhyay, N.R., Mazumder, B., \& Mazumdar, B. 2002. Induced spawning of Pangasius suthci with pituitary extract. Aquaculture Asia, VII(1): 43- 44.

Chevassus, B. 1983. Hybridization in fish. Aquaculture, 33: 245- 262.

Fuiman, L.A. 2002. Special consideration of fish eggs and larvae. In: L.A. Fuiman and R.G. Werner (eds.). Fishery Science: The Unique Contributions of Early Life Stages. Blackwell Publishing Company. Oxford, p. 1-32.

Gustiano, R. 2004. Biometric analysis of the artificial hybridization between Pangasius djambal Bleeker, 1846 and Pangasianodon hypophthalmus Sauvage, 1878. Indonesian J. of Agricultural Science, 5(2): 70- 74.

Gustiano, R. 2009. Pangasiid catfishes of Indonesia. Buletin Plasma Nutfah, 15(2): 91100.

Gustiano, R. \& Kristanto, A.H. 2007. Evaluation of hybridization between Pangasius djambal Bleeker, 1846 and Pangasianodon hypophthlamus (Sauvage, 1878): biometric characterization and growth analysis. Indonesian Aquaculture Journal, 2(1): 27- 33.

Gustiano, R. \& Pouyaud, L. 2005. Phenetic analysis of 28 species Pangasiid catfishes from Asia. Zuriat, 16(1): 66- 74.

Gustiano, R. \& Pouyaud, L. 2007. Taxonomy and genetic relationship of Pangasiidae, Asian catfishes, based on morphological and molecular analyses. Indonesian Aquaculture Journal, 2(2): 107- 112.

Gustiano, R. \& Pouyaud, L. 2008. Systematic revision of the genera of Pangasiidae (Siluriformes, Ostariophysi). Indonesian Aquaculture Journal, 3(1): 13- 22.

Haniffa, M.A., Dhanaraj, M., Ramakrishnan, C.M., Manju, R.A., Kumar, Y.A., \& Singh, S.V.A. 
2009. Hybridization between threatened freshwater catfish Mystus gulio (Hamilton \& Buchanan) and Mystus montanus (Jerdon) by artificial fertilization. Indian Journal of Experimental Biology, 47: 679- 683.

Hardjamulia, A., Djajadiredja, R., Atmawinata, S., \&Idris, D. 1981. Pembenihan jambal siam (Pangasius sutchi) dengan suntikan ekstrak kelenjar hipofisa ikan mas (Cyprinus carpio). Buletin Penelitian Perikanan, I(2): 183- 190.

Hassan, A., Ambak, M.A., \& Samad, A.P.A. 2011. Crossbreeding of Pangasianodon hypophthalmus (Sauvage, 1878) and Pangasius nasutus (Bleeker, 1863) and their larval development. Journal of Sustainability Science and Management, 6(1): 28- 35.

Islam, A. 2005. Embryonic and larval development of Thai Pangas (Pangasius sutchi Fowler, 1937). Development, Growth and Differentiation, 47: 1- 6.

Jalabert, B. 2008. An overview of 30 years international research in some selected fields of the reproductive physiology of fish. Cybium, 32(2): 7- 13.

Khan, M.H.K. \& Mollah, M.F.A. 2004. Further trials on induced breeding of Pangasius pangasius (Hamilton) in Bangladesh. Asian Fisheries Science, 17: 135- 146.

Kristanto, A.H., Subagja, J., Slembrouck, J., \& Legendre, M. 1998. Effect of eggs incubation technique on hatching rate, hatching kinetic and survival of larvae in the Asian catfish Pangasius hypophthalmus (Siluriformes, Pangasiidae). In: M. Legendre and A. Parisele (eds.). The Biological Diversity and Aquaculture of Clariid and Pangasiid Catfishes in South- East Asia. Proceeding of The Mid-Term Workshop of the Catfish Asia Project, 11-15 May 1998. Cantho-Vietnam, p. 107-111.

Legendre, M. 2008. Characterisation, utilisation and maintenance of biological diversity for the diversification and sustainability of catfish culture in SouthEast Asia. In: N. Estrella Santos and C.E. Nauen (eds.). Catalogue of Synopses of International S\&T Cooperative (INCO) Projects on Chalenges in Fisheries, Coastal Zones, Wetlands and Aquaculture. ACP- EU Fisheries Resources Report 17, p. 206- 207.

Legendre, M., Teugels, G.G., Cauty, C., \& Jalabert, B. 1992. A comparative study on morphology, growth rate and reproduction of Clarias gariepinus (Burchell, 1822),
Heterobranchus longifilis Valenciennes, 1840, and their reciprocal hybrids (Pisces, Clariidae). Journal of Fish Biology, 40: 5979.

Legendre, M., Slembrouck, J., \& Subagja, J. 1998a. First result on growth and artificial propagation of Pangasius djambal (Siluriformes, Pangasiidae) in Indonesia. In: M. Legendre and A. Parisele (eds.). The Biological Diversity and Aquaculture of Clariid and Pangasiid Catfishes in South- East Asia. Proceeding of The Mid- Term Workshop of the Catfish Asia Project, 11- 15 May 1998. Cantho - Vietnam, p. 97- 102.

Legendre, M., Slembrouck, J., Subagja, J., \& Kristanto, A.H. 1998b. Effect of varying latency period on the in vivo survival of ova after Ovaprim- and hCG- induced ovulation in the Asian catfish Pangasius hypophthalmus (Pangasiidae, Siluriformes). In: M. Legendre and A. Parisele (eds.). The Biological Diversity and Aquaculture of Clariid and Pangasiid Catfishes in SouthEastAsia. Proceeding of The Mid-Term Workshop of the Catfish Asia Project, 11- 15 May 1998. Cantho - Vietnam, p. 119- 125.

Legendre, M., Slembrouck, J., Subagja, J., \& Kristanto, A.H. 2000a. Ovulation rate, latency period and ova viability after $\mathrm{GnRH}$ or hCG-induced breeding in the Asian catfish Pangasius hypophthalmus (Siluriformes, Pangasiidae). Aquatic Living Resources, 13: 145- 151.

Legendre, M., Subagja, J., \& Slembrouck, J. 1998c. Absence of marked seasonal variations in sexual maturity of Pangasius hypophthalmus brooders held in Sukamandi Station (Java, Indonesia). In: M. Legendre and A. Parisele (eds.). The Biological Diversity and Aquaculture of Clariid and Pangasiid Catfishes in South- East Asia. Proceeding of The Mid- Term Workshop of the Catfish Asia Project, 11- 15 May 1998. Cantho-Vietnam, p. 91- 96.

Legendre, M., Pouyaud, L., Slembrouck, J., Gustiano, R., Kristanto, A.H., Subagja, J., Komarudin, O., Sudarto, \& Maskur. 2000b. Pangasius djambal: a new candidate species for fish culture in Indonesia. Indonesian Agricultural Research and Development Journal, 22(1): 1- 14.

Lenormand, S., Slembrouck, J., Pouyaud, L., Subagja, J., \& Legendre, M. 1998. Evaluation of hybridisation in five Clarias species (Siluriformes, Clariidae) of African ( $C$. 
gariepinus) and Asian origin (C. batrachus, C. meladerma, C. nieuhofii and $C$. teijsmanni). In: M. Legendre and A. Parisele (eds.). The Biological Diversity and Aquaculture of Clariid and Pangasiid Catfishes in South- East Asia. Proceeding of The MidTerm Workshop of the Catfish Asia Project, 11- 15 May 1998. Cantho- Vietnam, p. 195209.

LRPTBPAT. 2006. Dokumen Usulan Pelepasan Patin Hibrida. Loka Riset Pemuliaan dan Teknologi Budidaya Perikanan Air Tawar. Sukamandi, $14 \mathrm{hlm}$.

Mattson, N.S., Buakhamvongsa, K., Sukumasavin, N., Nguyen, T., \& Vibol, O. 2002. Cambodia Mekong giant fish species: on their management and biology. MRC Technical Paper No. 3. Mekong River Commission. Phnom Penh, 31 pp.

Mollah, M.F.A., Amin, M.R., Sarowar, M.N., \& Muhammadullah. 2008. Induced breeding of the riverine catfish Rita rita. Journal of Bangladesh Agricultural University, 6(2): 361- 366.

Meng- Umphan, K., Manosroi, J., \& Manosroi, K. 2006. Successful artificial breeding of the Mekong Giant Catfish (Pangasianodon gigas, Chevey) reared in earthen ponds by boostering with gonadotropin releasing hormone analogue (GnRHa). Asian Fisheries Science, 19: 149- 155.

Pouyaud, L., Teugels, G.G., \& Legendre, M. 1999. Description of a new pangasiid catfish from South- East Asia (Siluriformes). Cybium, 23(3): 247- 258.

Puvaneswari, S., Marimuthu, K., Karuppasamy, R., \& Haniffa, M.A. 2009. Early embryonic and larval development of Indian catfish, Heteropneustes fossilis. EurAsian Journal of BioSciences, 3: 84- 96.

Rahman, M.R., Rahman, M.A., Khan, M.N., \& Hussain, M.G. 2004. Observation on the embryonic and larval development of silurid catfish, Gulsha (Mystus cavasius Ham.). Pakistan Journal of Biological Sciences, 7(6): 1,070-1,075.

Ramanathan, N., Natarajan, P., \& Sukumaran, N. 1985. Studies on the induced spawning and larval rearing of a freshwater catfish, Mystus punctatus (Jerdon). Proceeding of Indian Academic Science (Animal Science), 94(4): 389- 398.

Roberts, T.R. \& Vidthayanon, C. 1991. Systematic revision of the Asian catfish family Pangasiidae, with biological observations and description of three new species. Proceedings of the Academy of Natural Sciences of Philadelphia, 143: 97- 144.

Sarkar, U.K., Paul, S.K., Kapoor, D., Deepak, P.K., $\&$ Singh, S.P. 2006. Captive breeding of pangasid catfish Pangasius pangasius with Ovaprim - an attempt towards sustainable seed production and conservation of wild populations. Aquaculture Asia, X(3): 8- 10.

Slembrouck, J., Pamungkas, W., Subagja, J., Hadie, W., \& Legendre, M. 2003. Biological of larvae. In: J. Slembrouck, O. Komarudin, Maskur and M. Legendre (Eds.). Technical Manual for Artificial Propagation of the Indonesian Catfish, Pangasius djambal. IRDDKP. Karya Pratama. Jakarta, p. 95- 103.

Sriphairoj, K., Klinbu-nga, S., Kamonrat, W., \&NaNakorn, U. 2010. Species identification of four economically important Pangasiid catfishes and closely related species using SSCP markers. Aquaculture, 308: S47- S50.

Sudarto. 1999. Karakterisasi genetik dan zooteknik ikan lele (Clariidae) dan patin (Pangasiidae) dari wilayah Asia Tenggara. Makalah dalam: A. Hardjamulia, K. Sumantadinata, K. Sugama, A. Sudradjat dan E.S. Heruwati (Eds). Prosiding Seminar Hasil Penelitian Genetika Ikan, Jakarta, 8 Februari 1999, hlm. 26- 29.

Tahapari, E., Iswanto, B., \& Sularto. 2007. Perkembangan ovari dan oosit ikan patin hasil persilangan antara betina patin siam (Pangasianodon hypophthalmus) dengan jantan patin jambal (Pangasius djambal). Aquacultura Indonesiana, 8(2): 73- 80.

Tahapari, E., Iswanto, B., \& Sularto. 2008. Keragaan reproduksi patin nasutus (Pangasius nasutus) dan pertumbuhan anakannya. Laporan Teknis Hasil Penelitian Tahun Anggaran 2008. Loka Riset Pemuliaan dan Teknologi Budidaya Perikanan Air Tawar. Sukamandi, $12 \mathrm{hlm}$.

Tahapari, E., Iswanto, B., Nurlaela, I., \& Sularto. 2010a. Embriogenesis dan perkembangan morfologis larva patin nasutus, Pangasius nasutus Bleeker, 1863 (Pangasiidae, Siluriformes). Makalah dalam: A. Husni, Suadi dan I. Istiqomah (penyunting). Prosiding Seminar Nasional Tahunan VII Hasil Penelitian Perikanan dan Kelautan Tahun 2010. Yogyakarta, 24 Juli 2010, 9 hlm.

Tahapari, E., Suryaningrum, Th. D., \& Nurlaela, I., 2010b. Profil sensori dan nilai gizi beberapa jenis ikan patin. Laporan Teknis 
Hasil Penelitian Tahun Anggaran 2010. Loka Riset Pemuliaan dan Teknologi Budidaya Perikanan Air Tawar. Sukamandi, $24 \mathrm{hlm}$.

Wang, W.M., Abbas, K., \&Yan, A.S. 2006. Embryonic development of Pelteobagrus fulvidraco (Richardson, 1846). Chinese Journal of Oceanology and Limnology, 24(4): 378- 383.

Wang, D.S., Zhang, Y.G., \& Luo, Q.S. 1992. Observations on the larval development of Mystus macropterus (Bleeker): Bagridae. Journal of Fish Biology, 40: 371- 379.
Watanabe, K. 1994. Mating behaviour and larval development of Pseudobagrus ichikawai (Siluriformes: Bagridae). Japan Journal of Ichthyology, 41(3): 2443- 251.

Xuan, L.N. \& Liem, P.T. 1998. Preliminary results on the induced spawning of two catfish species, Pangasius conchophilus and Pangasius sp1. in the Mekong Delta, Vietnam. In: M. Legendre and A. Parisele (Eds.). The Biological Diversity and Aquaculture of Clariid and Pangasiid Catfishes in SouthEast Asia. Proceeding of The Mid-Term Workshop of the Catfish Asia Project, 11- 15 May 1998. Cantho- Vietnam, p. 103- 106. 